\title{
Reinventing a Better and Effective Institutional Framework for Efficient Watershed Management, Agriculture Development and Progress of Village Communities in Rural India: VDMO
}

\author{
Anil Kumar Mishra ${ }^{1 *}$ and B. S. Kalra ${ }^{2}$ \\ ${ }^{1}$ Soil and Water Conservation Engineering, Water Technology Centre, ICAR-Indian Agricultural \\ Research Institute, New Delhi - 110012, Delhi, India \\ ${ }^{2}$ Water Technology Centre, ICAR-Indian Agricultural Research Institute, New Delhi - 110012, Delhi, India
}

\begin{abstract}
The development of grass root level institutions is central to sustainable agricultural development, inclusive of healthy natural resource base and redistribution of income in favour of resources poor farmers to enable the local communities to be part of the whole in the matters of planning and execution. Various watershed management programmes have shown varying level of success based on the procedure of field implementation of such project and level of people's participation. Many projects have drastically failed despite the water availability during the active rainfall periods whereas some project were quite successful despite continuous monsoon failures in a row. Scenario analysis of some successful watershed management programme and lessons learnt from the past experiences based on the field surveys, interviews of individuals, farmers, village leaders, development officials of the government etc. have been analyzed and inferences have been drawn. Results from the study of some of the famous watershed development programs implemented in the past in India, lead by dedicated grass root workers; revealed that the process and the manner in which activities were implemented are as important as the activities of the people. It was observed that the successes and the pitfalls in the development of peoples centered/farmers led participatory watershed management in India depend on mainly four factors namely; whole hearted people's participation, the most sincere and dedicated contribution of an honest leader of people and a thorough and comprehensive analytical frame work for project planning and implementation either by any individual or by the government. An institutional framework incorporating general trend of decentralization and peoples participation is proposed for effective implementation of such program. In the present study a new model for the overall development and management of resources of the rural agrarian economy of India has been envisaged. Such grass root level institution, called Village Development and Management Organization (VDMO), will be working in close association with rural masses and will have responsibility to protect their interests. It is a three tier developmental model for local self government based on the decentralized developmental principles. This also is a closed chain business model for earning profits using local resources with sustainability by all beneficiaries. It will create strong and transparent processes in local resources management, conceiving and field implementation of developmental projects, employment generation ventures, capacity building and bringing in enormous happiness without and socio-cultural or economic biases.
\end{abstract}

Keywords: Institutions, Livelihood, Management, Natural Resources, Villages, Water, Watersheds

*Email: dranilkumarmishra1@gmail.com 


\section{Introduction}

The institutional arrangements for rainwater harvesting at grass root levels never evolved as professional and responsible bodies with long term perspective failed to understand the exact mechanism of its working (Anonymous, 1957; Nehru, 1964; World Bank, 2000). Our country, India is blessed by nature with ample water resources in form of high annual average rainfall (Anirban, 1989; Aziz et al, 2002; Babu, 2005, 2009; Hardgrave and Kochanek, 2008) but with spatially and temporally varying amounts as well as large changes over the cropping seasons. It has been estimated that the mean annual average rainfall in our country is 1170 $\mathrm{mm}$ (Table 1, CWC, 2019). Total generation of annual runoff is equivalent to 400 million-hectare meters (m ha-m) of water. Out of his nearly $180 \mathrm{~m}$ ha-m surface run-off is available for harnessing but most of it $(150 \mathrm{~m}$ ha-m) flows to the sea and a small quantity (30 m ha-m) is stored in the ground water. While the large part of our country gets a much better share of the rainfall through south west monsoon or north east (SW or NW), only a very small proportion of total geographical area (the western Rajasthan) receives an annual average rainfall less than $500 \mathrm{~mm}$ (Table 1). The main body that is responsible for development and management of all surface water resources in our country is the Central Water Commission. The Central Ground Water Board (CGWB), however, is responsible for development and management of ground water resources. On the basis of availability of monsoon run-off and storage potential of vadose zone (unsaturated zone between the land surface and the zone of saturation), the CGWB has estimated an additional ground water storage $21.42 \mathrm{~m}$ ha-m of which $16.05 \mathrm{~m}$ ha-m can be safely utilized. It has a Master Plan for artificial recharge to groundwater to recharge 36155 million cubic meters of surface run-off in about $448760 \mathrm{sq} \mathrm{km}$ of water deficit areas in the country by the construction of 225 thousand recharge structures in rural areas at an estimated cost of Rs. 198800 million over a period of 10 years in collaboration with local communities/ Panchayats and NGOs (Ram, 2008). In such situations, it is generally recognized that in-situ as well as ex-situ water conservation and better management efforts offer vast scope for enhancing water availability and mitigating the shortages.
It has been estimated that the water resources in this country are shrinking due to many reasons including climate change. Efforts to harvest, conserve, store and manage the precious water resources are not made adequately and timely when it is freely available as rainfall. Hence, the growing scarcity of water, amidst plenty, is a result of inadequate, unscientific management. It is also evident from the inability of agriculture to cope with impact of fluctuations in rainfall. Over exploitation of groundwater resources is one of the most serious manifestation of this phenomenon. It is evident from the fact that over exploited and dark blocks in the country have increased from 253 in 1985 to 1098 in 2004 besides recording of steep decline in groundwater levels in 300 districts over the years. According to another estimation about one fourth of India's harvest is at risk from groundwater depletion (Figure $1 \& 2$ ). The crisis, however, is not about having too little water to satisfy our needs (The World Water Council) rather it is poor management of available water resources that has created an artificial gap between demand and supply of water" (Sharma, 1987; Singh, 2003; Rajasekhar and Manjula, 2010). The loomig crisis of climate change has adversely affected the water availability in the entire country which has started facing growing dryness over the past two decades (Figure $1 \& 2$ ). The seasonal [Winter (Jan - Feb), Summer (March - May), Monsoon (June - Sept), Post-monsoon (Oct - Dec)] and Yearround rainfall of major stations of India as reorted by the India Meteorological Department (IMD, 2020) is given in (Table 1).

\section{Watershed Development Programmes in India: A Case of Sporadic Limited Success}

All-natural resources in India were owned either by the kings or by their representatives before Mughal invasion. During this period the land records were systematized and during the reign of Akbar, SH. Toadrmal made such a fool proof system of land management that is still having no parallels. During the British raj followed Zamindari with once again well-structured resources distribution amongst the masses but only to the selected few who were responsible to collect the cess from the cultivators called as Raiyat or Malgujari in local 
language. After independence and more precisely after Bhoodan Andolan initiated by Baba Vinoba Bhave only the masses could have some right on land they cultivated except in the Tribal dominant regions but there were not many changes in the situation even after the independence. Hence, prior to independence, water conservation programmes was the responsibility of locals who did it as a tradition and many sacred traditions rituals got associated with is in almost all the regions. After independence, these became the responsibility of the State (even during British Raj too; with the advent of colonial rule) due to the reason that the State took control of all-natural resources.

States were empowered to make laws regarding the management of resources as it was state subject as per the Indian Constitution (GOI, 1993; Mathew, 1994). Therefore, the states were free to legislate in this regard and in most cases colonial laws are still in force. The Bihar Irrigation Act, 1997 also provides that all rights in surface water vest in the Government. The conservation, management and most efficient use of natural resources were grossly neglected in absence of efforts for regeneration, stood over-exploited (Mullick and Raj, 2007) mainly due to the weak implementation machinery of the State led institutions. Slowly the masses were grossly alienated from the resources that were already jeopardized due to over exploitation and scanty. Even in such conditions of resources scarcity some local leaders, reformers and village elders cae forward to undertake the work of conservation and restoration which resulted into some successful conservation programmes in the country viz.; Ralegan Sidhi (Maharashtra), Alwar (Rajasthan), Jhamka (Gujarat), Gaya (Bihar), Laporia (Rajasthan). Apart from various state run programmes for land and water conservation, afforestation, rainwater harvesting and management programmes were implemented on watershed basis as community/farmer led programmes for management of vital commodities. In this scenario, Some traditional isolated local initiatives in various parts of the country, successfully implementing the land and water resources conservation programmes as traditional ingenuity like Apatani (arunachal Pradesh), Jabo (Nagaland) and Panikheti (Sikkim) are few glittering examples of successful implementation of community led resources management programmes in India after independence.

The success of these programmes can be attributed to the philanthropic initiatives of some persons having native interests in the resources conservation of management or the local traditions borrowed from the ancestors of specific region. In tribal culture the local community, after developing strong faith in the leadership, organized themselves in the form of village level management committees and undertook measures for soil and water conservations (Bahl, 2002; Balakrishnan, 2007; Bird, 2000). However, when a local leader was behind such programme it was his selfless motives and understanding of local social and agro-economic problems and an appeal to the local community to ameliorate their lot were the main characteristics of the process of implementing the solutions with objectives of public service (Inbanathan, 2003, 2010).

\subsection{Reasons behind Successful Watershed Management Programmes}

The process and the methodologies of implementation were the major reasons for the successful implementation of some very successful watershed management programmes in this country. In majority of the successful projects field implementation process were based on local socio-economic conditions, scientific and sound delivery mechanism owned by the local community, and commitment from the project implementing agencies, which happened to be the local committees working under the guidance of a popular local leader whose integrity was beyond doubts of any kind. Some successful projects created forums for collective decision making and ensuring representation of all the stake holders. Now a days all such forums have not only become autonomous but also have resources of their own or entrusted with public money and worked to address their immediate constraints (Vijayalakshmi, 2007, Bollongino et al., 2013, Thomas, and Richard, 2000). Further, additional monetary resources are automatically generated once the sound project implementation system are in place. Empowerment of poor through building their capabilities, access to sustainable livelihood and opportunities for off-farm 
work were part and parcel of the processes adopted. It has been amply demonstrated that improved and successful watershed management programmes were not so much a matter of monetary allocations, but a result of project implementation processes and sensible governance.

\subsection{Successful Implementation of Watershed Development Program: Rural Grass Root Level Institutions and their Role in Natural Resources Management}

Many state governments departments attempted to undertake programmes on natural resources management or watershed development in different regions of the country and met with varying success. The main reason for limited success can be attributed primarily to the larger scale or wide areal coverage for which the successful programs were taken up by the respective state agencies for implementation over a given period of time. However, most of these programmes ended up with hegemony of government departments and could not replicate the success stories in collaborative mode (Sisodia, 1971; Udgaonkar, 1986; Rajaraman and Garima, 2000; NCERT, 2019) as demonstrated by those programmes which were implemented by the people under the leadership of an honest and committed local leader. For many performance indicators, the government projects did not perform any better than non-project villages. The government programs bring in monetary resources and the legitimacy to the actions but lack the dynamics of interaction with local population with different expectations and behavioral norms. People did not trust and volunteer to work in unison with the government officials who have not learnt to take up position of a local leader. Very few NGOs possess skills necessary for community involvement and their target-oriented existence contribute to the success of the program. However, the number of such voluntary organizations is very small and given the nature, development of such institutions is also not common. Further, there is vast scope to widen its membership by inviting and assimilating in local personalities of repute (Rao et al., 2004).
Local government, non-government, voluntary or autonomous institutions operating in an area are the main interface between natural resources and rural dwellers. Institutions are the formal or informal "rules of the game" which guide human interaction with natural resources. The disequilibrium between demand and supply (economic functions performed) have been brought by the accelerated economic growth and population explosion in the country with more exchanges, specializations and linkages to the rest of the world of institutions in rural sector (Pellissery, 2007). The old traditional village level institutions, formal or informal have crumbled with the new political order in independent India. Hence, majority of them are no longer adequate and capable of managing the natural resources in fast expanding and increasingly integrating rural and modern economies. Given the limited number of such organizations, mostly government departments, and the massive need and ambitions plans for natural resources and watershed development, inextricably linked with agricultural production systems, the implementation capacity possess a serious challenge. These arrangements never evolved as professional, responsible, democratic bodies with long term perspective and power and possessed no authority to undertake major decisions at grass root levels on implementation or future actions based on the past experiences (Bhargava and Raphel, 1994; Beseley, et al., 2008; Anonymous, 2020).

The growing understanding of the situation has put the belief more firmly that the watershed management and improving the economic access of poor to food and supporting poor on trajectory out of poverty is not so much a matter of off-the-shelf technology transfer and additional resources, as of better policies, sound delivery mechanisms and commitments to improve programme management and governance. Evaluation of some of the famous watershed development programs revealed that the success was achieved in the projects due to empowerment of poor through building their capabilities, access to sustainable livelihood and opportunities for off-farm work. On the contrary, projects benefited by creating forums for collective decision making and ensuring representation of poor were higher. These 


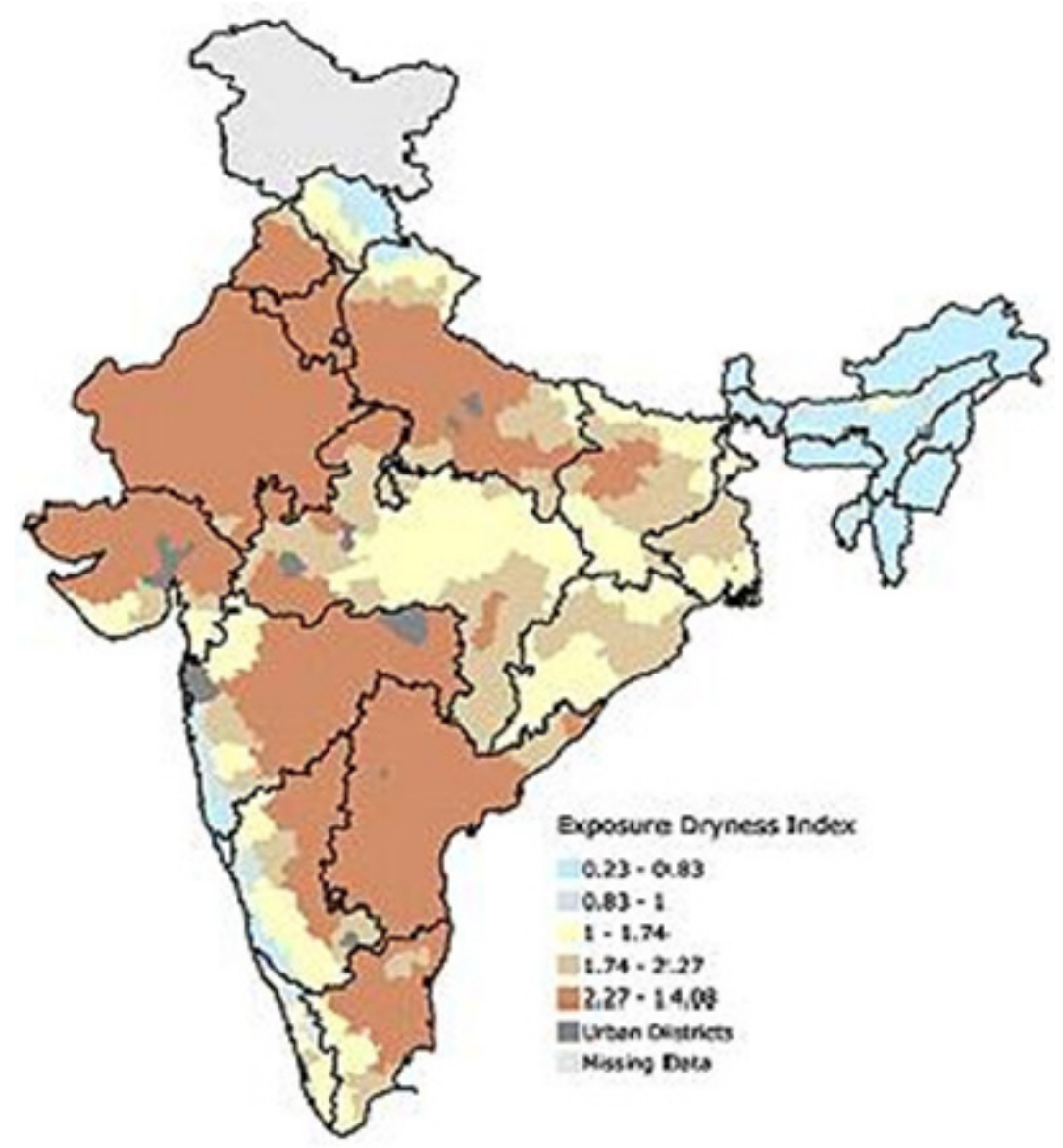

Figure 1. Exposure dryness index in India (Source: IMD).

Table 1. Average precipitation in various Indian cities ( $\mathrm{mm}$ )

\begin{tabular}{|c|c|c|c|c|c|c|c|c|c|c|c|c|c|}
\hline \multirow{2}{*}{$\begin{array}{l}\text { Season } \\
\text { City }\end{array}$} & \multicolumn{3}{|c|}{$\begin{array}{c}\text { Winter } \\
\text { (Jan - Feb) }\end{array}$} & \multicolumn{3}{|c|}{$\begin{array}{c}\text { Summer } \\
\text { (Mar - May) }\end{array}$} & \multicolumn{3}{|c|}{$\begin{array}{l}\text { Monsoon } \\
\text { (Jun - Sep) }\end{array}$} & \multicolumn{3}{|c|}{$\begin{array}{c}\text { Post-monsoon } \\
\text { (Oct - Dec) }\end{array}$} & \multirow{2}{*}{$\begin{array}{c}\text { Year-round } \\
\text { Total }\end{array}$} \\
\hline & Jan & Feb & Mar & Apr & May & Jun & Jul & Aug & Sep & Oct & Nov & Dec & \\
\hline Bangalore & - & - & 10 & 30 & 110 & 70 & 100 & 130 & 170 & 150 & 60 & 10 & 900 \\
\hline Chennai & 36 & 10 & 8 & 15 & 25 & 48 & 91 & 117 & 119 & 305 & 356 & 140 & 1,270 \\
\hline Guwahati & 8 & 21 & 47 & 181 & 226 & 309 & 377 & 227 & 199 & 92 & 25 & 10 & 1,722 \\
\hline Kolkata & 10 & 31 & 36 & 43 & 140 & 297 & 325 & 328 & 252 & 114 & 20 & 5 & 1,601 \\
\hline Mumbai & 3 & 3 & 3 & 0 & 18 & 485 & 617 & 340 & 264 & 64 & 13 & 3 & 1,813 \\
\hline Nagpur & 16 & 22 & 15 & 8 & 18 & 168 & 290 & 291 & 157 & 73 & 17 & 19 & 1,094 \\
\hline New Delhi & 23 & 18 & 13 & 8 & 13 & 74 & 180 & 173 & 117 & 10 & 3 & 10 & 642 \\
\hline Port Blair & 40 & 20 & 10 & 60 & 360 & 480 & 400 & 400 & 460 & 290 & 220 & 150 & 2,890 \\
\hline Srinagar & 74 & 71 & 91 & 94 & 61 & 36 & 58 & 61 & 38 & 31 & 10 & 33 & 658 \\
\hline
\end{tabular}

Source: IMD, 2020

forums enjoy autonomy, have resources of their own and worked according to certain defined social norms. Reposing faith in community and allowing them to handle activity resulted in well targeted cost-effective project benefits. This significantly impacted the degree to which decisions were aligned to local preferences and needs of the poor. Thus, involvement of local populace in the social reforms or changes is very important as activities to the people have been the process and the manner in which activity was implemented 


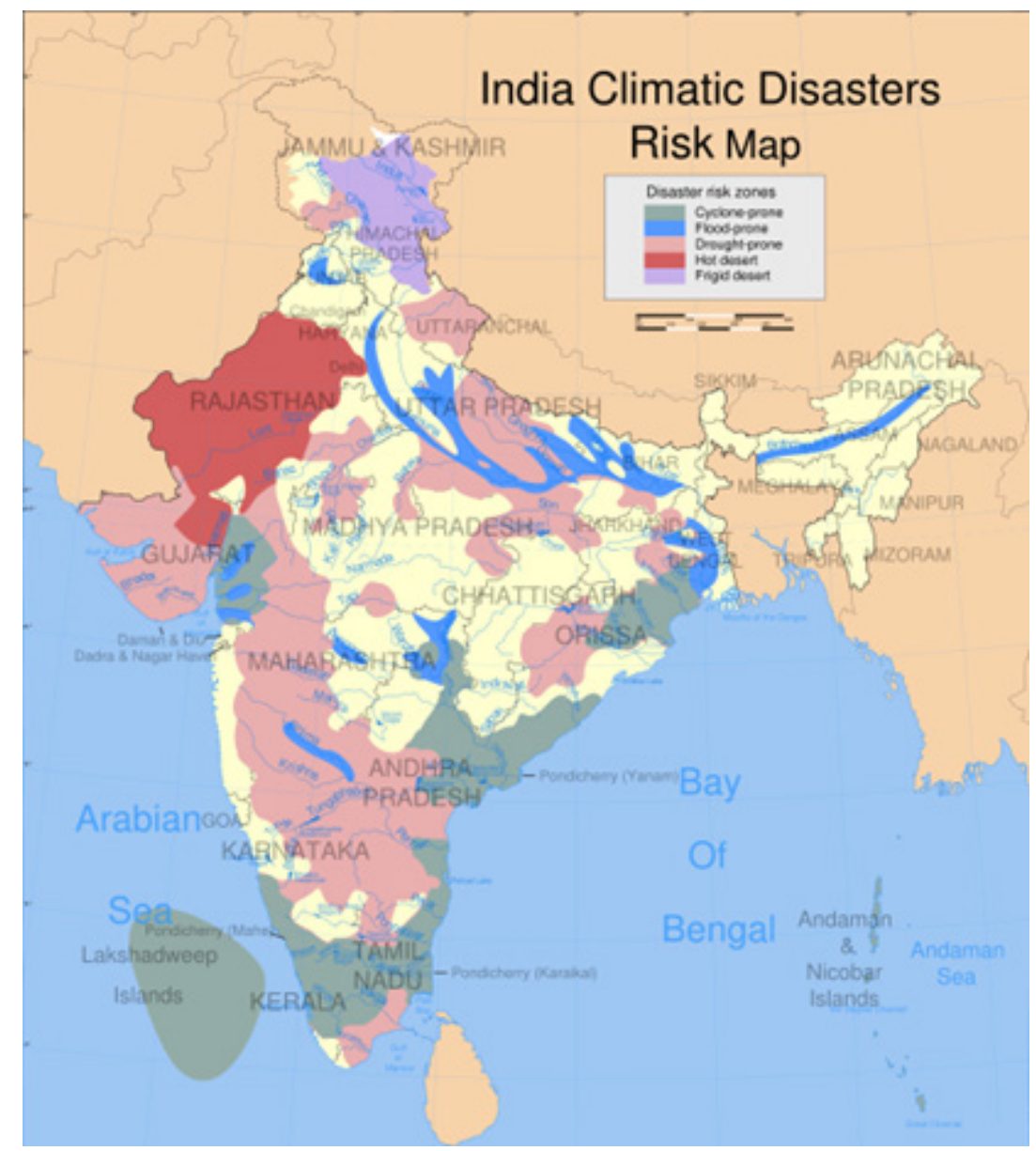

Figure 2. Climate disaster risk prone zones in India (Source: The Internet)

(George, 2000; Chattopadhyay and Duffo, 2004; Fahim, 2009).

\subsection{Present Institutional Scenario}

The watershed development so far remained synonymous with soil and water conservation by implementing physical measures like water and soil harvesting structures. This didn't automatically lead to higher productivity and sustained livelihood. In fact, development of livelihood, which included farm production system as well as off-farm livelihoods, continues to receive low attention under watershed programs. Thenational agricultural support programs like fertilizer, power and irrigation subsidies, procurement and price support, by - passed the rainfed agriculture. This historic neglect has created a very high degree of indifference on parts of farmers and business towards rainfed agriculture. National Water Policy, while emphasizing the development and management of water resources on a hydrological unit basis, advocate that 'management of water resources for diverse uses should incorporate a participatory approach by involving not only the various governmental agencies but also the users and other stake-holders, in an effective and decisive manner, in various aspects of planning, design, development and management of the water resources schemes. Exposure dryness index in India is shown in Figure 1 while the climate disaster risk prone zones in India is shown in Figure 2. It can be seen from these figures that almost every year or every alternate year some or other part of India faces serious challenges for natural resources degradation requiring sustained efforts for their management. The unimodal 
monsoon climate is yet another serious problem in the progress of the country as during this period nearly half to two third country faces serious challenges of water abundance leading to landslides, floods and related issues (Table 1). Therefore, necessary legal and institutional changes should be made at various levels for the purpose, duly ensuring appropriate role for women.

\subsubsection{Need for Revamping the Existing Infrastructure}

The vast number of mid-term reviews, impact evaluation and exploratory studies suggested that the programs implemented by the state departments in partnership with local communities are not a success story. The effectiveness of programmes is low across States and problem of poor delivery is endemic. In these models the user groups have no statuary authority over the resource independent of particular department programme or project. They have little autonomy to develop strategy for the development of resources. The schemes are left to be planned and executed by district level officers which, in most cases, are also PIAs. Under hierarchical bureaucratic set up, the capability of these officers to do planning and involve masses at grass root level is extremely limited. Decision making power rests with those at the apex of the organization and project activities simply required delivery of offthe shelf technological activities. The ability to respond to clients' needs is hardly built up in the procedures and they are not accountable to local community. A highlevel committee headed by Prof. Hanumantha Rao in 1993 reviewed the watershed development programs comprehensively and held some factors responsible for their unsatisfactory performance. These are i) multitude of activities over widely dispersed areas of very small sizes, ii) ad-hoc planning without people's involvement, iii) non - viable work plans in the absence of multidisciplinary agency at watershed, block and district level, plans not oriented to local needs and activities not taking cognizance of indigenous technologies, iv) no appropriate mechanism for maintenance of created assets.

Watershed Development Committee, Water User's Associations, Farmers Producers Organization, any other voluntary association or group, Yuvak Mangal Dal etc. and the local bodies such as urban Municipalities and Gram Panchayats should particularly be involved in the operation, maintenance and management of water infrastructure/facilities at appropriate levels progressively, with a view to eventually transfer the management of such facilities to the use's groups/local bodies. Thus, in line with this and the general liberalization and decentralization process initiated in 1991 in the country and based on recommendation of various high-powered committees, Government of India formulated the Guidelines for Watershed Development and these were put in operation with effect from w.e.f. April 1995. In a continuous process of evaluation and change these guidelines were subjected to modifications in order to bring about convergence among various departments and making these guidelines functionally more useful and efficient. Thus, Common Approach for Watershed Development, Guidelines for Watershed Development (Revised - 2001), WARSA Jan Sahbhagita: Guidelines have been brought out. The latest version of guidelines - HARIYALI guidelines have sought the partnership through constitutionally recognized Panchayati Raj Institutions (PRIs).

\subsubsection{Suggested Path for Better and Emphatic Implementation of Programmes}

There are major departures from previous approaches, which promise to lay the foundation for a paradigm shift in institutional arrangements to manage water and other natural resources. These reports contain suggestions, which could be called revolutionary with far reaching consequences. These reports recommended Farmer Led, Integrated, Participatory approach involving the communities and weaker gender ensuring their full cooperation and participation at grass root level. Local inhabitants are empowered to initiate activities, which they consider most appropriate to meet their requirements and also involve the implementation ability of the beneficiary population at the local level. In this scheme, the planning and the execution works under the projects have been entrusted to the local community. The local community is free to choose appropriate technology, which may be the local innovations evolved by the community. The 
various provisions under the guidelines provide for a regime where power is exercised "by" the people and not "for" the people. Project Implementing Agency (PIA) is another very crucial agency in this process of watershed development. While the main development activities will be carried out by the watershed community itself, the overall facilitation by way of organizing watershed committees, providing technological input, coordinating with other agencies like credit institutions, research organization and state government departments etc will be the responsibility of PIA. The PIA is also empowered to engage persons with specialization in required field of interest like, agronomy, horticulture, agricultural engineering, forestry, animal sciences or other basic sciences to carry out the task scientifically and efficiently.

\subsection{Panchayati Raj Institutions (PRI) in India}

Several arguments have been made for PRIs especially the Gram Panchayats, playing a central role in decentralized watershed management programmes. Gram Panchayats have rights over the natural resources within their boundaries and also have the mandate to plan local development and integrate various activities (Beseley et al., 2008). Constitutional (73 ${ }^{\text {rd }}$ Amendment) Act, 1993, have created a 3-tier Panchayati Raj Institutions (PRIs) for local self-governance (GOI, 1993), in which Gram Panchayat is the village level body of elected representatives. Gram Sabha (the general village assembly), which is inseparable part of Gram Panchayat, is the forum where marginalized poor can influence decisions affecting their lives. PRIs together, by definition, are able to "scale-up" activities as they are vertically integrated into political structure. Gram Panchayats have a constitutional commitment to represent the marginalized sections of the community through reserving a third of seats for them.

\section{Methodology}

Despite the apparent potential, there are many reasons why PRIs may not be the appropriate institutions to ensure watershed development. Gram Panchayat is very often elected on the basis of many social issues in the villages. Members, generally illiterate, have little idea of the role they are supposed to play. A village has got socially and economically diverse population and demographic imbalances do exist in all of them. National level political affiliations are not very uncommon. After $73^{\text {rd }}$ Constitutional Amendment, Gram Panchayats are delegated more responsibilities and there is increased fund flow. Therefore, elections to it have also assumed more prestige and powers. The seats are mostly cornered by persons with money and muscle power and they represent the interest of rich and influential section. Seats are reserved for women and unprivileged category of social groups but impact is less due to prevailing patriarchal system and proxy candidates. Gram Panchayats lack the technical expertise and the financial capacity to hire technical experts to intervene in watershed management on their own. The programme implementation procedures through contractor under supervision of state officials have not changed much. Often forgotten fact about poor implementation of the programme are the strict vigil and lack of technical evaluation during the field implementation of the programmes. Despite devolution, the block functionaries continue to have upper hand and there is hardly any diminution in their powers in post $73^{\text {rd }}$ Amendment scenario. In the process, the Gram Panchayats have come to stay as the lowest rung of bureaucratic delivery system.

\subsection{Reinventing a Modern Institutional Framework for a Grass Root Level Institution}

Based on the empirical assessment of watershed management programs in the country an institutional framework incorporating general trend of decentralization and people's participation is proposed for effective implementation of such programs. It is visualized from the following perspectives (Figure 3 and Figure 4).

It is suggested that these perspectives can be operationalized in two institutional environments, that is,

A) Open chain network with dynamically evolving partners and local communities and 


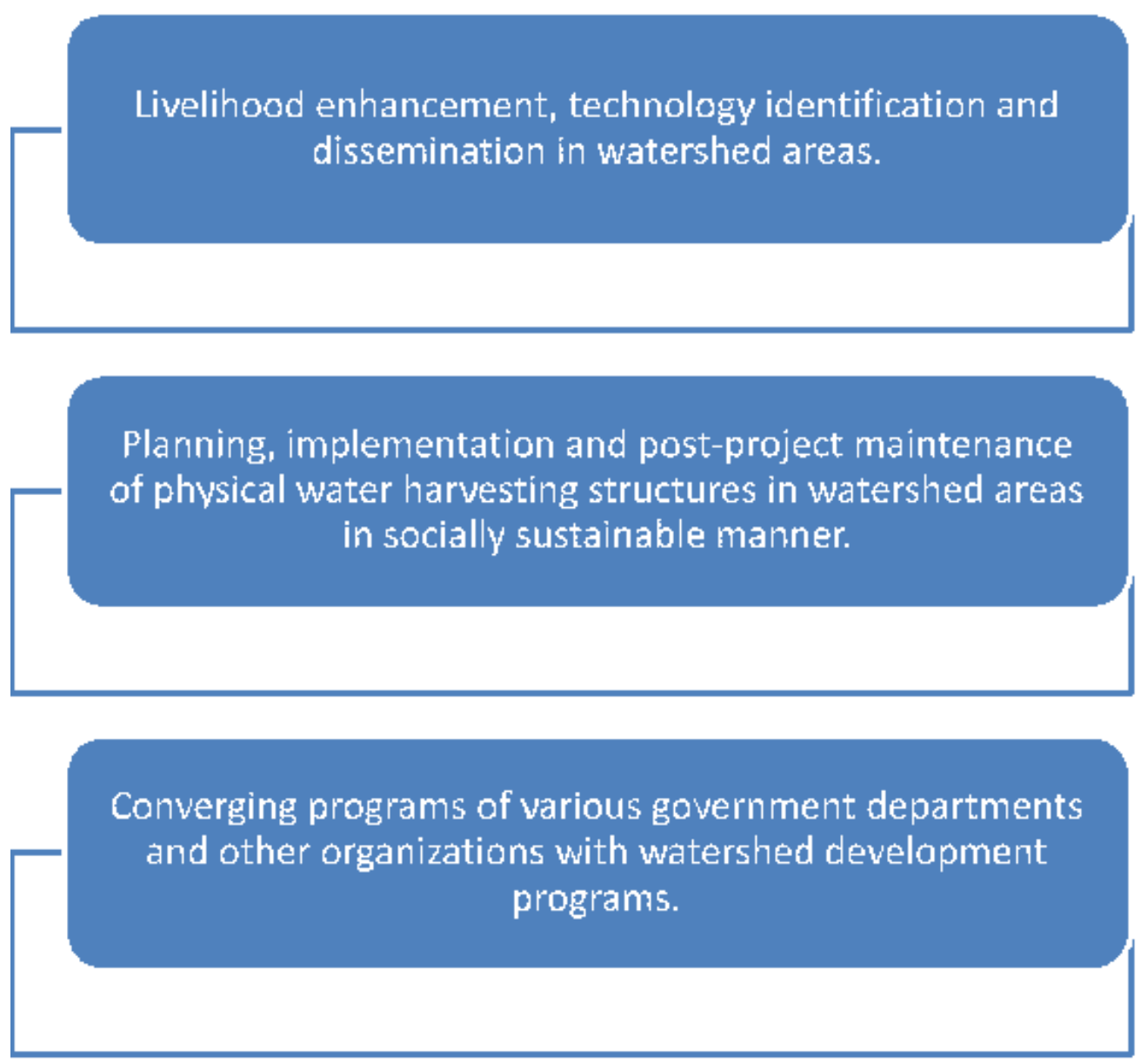

Figure 3. Proposed trend of decentralization and people's participation for effective implementation of such programs in India.

B) Closed vertical activity-based chain network within clearly defined participatory agri-business enterprises.

\subsection{Network Organizational Structure}

Many local institutions are in operation especially in remote underdeveloped villages in traibal dominated area wherein some universally acclaimed, undisputed persons accepted as their representative command such authority that all people abide by whatever decision are taken. After the independence of our country, adption of the new constitution and new order of democratic set up many such institutions have crumpled. Further, introduction of the panchayti raj system and mechanism of election has grossly divided the local village socital structure damaging its earstwhile uniqueness despite bringng some of the modernities. The Gram Swaraj Act of Madhya Pradesh was introduced to curb some of the authoritarian powers of the Sarpanch of the Head of the Panchayat. A subsidiary committees was introduced in the village governance and allowed to undertake and fulfill well defined goals based on clearcut and specific actions. Even such changes were grossly inefficient requiring more modifications in evolution of a metamorphic version of these institutions. In the new proposed concept of Village Development and Management Organization (VDMO) some of the characteristics of such organizations, are contemplated and innumerated in the following paragraphs.

Similarly, the new initiative of the Government like Agricultural Technology Management Agency (ATMA) is a relatively better concept but it operates across the boundries of the village panchayats at district level. It may be considered as an improvement 


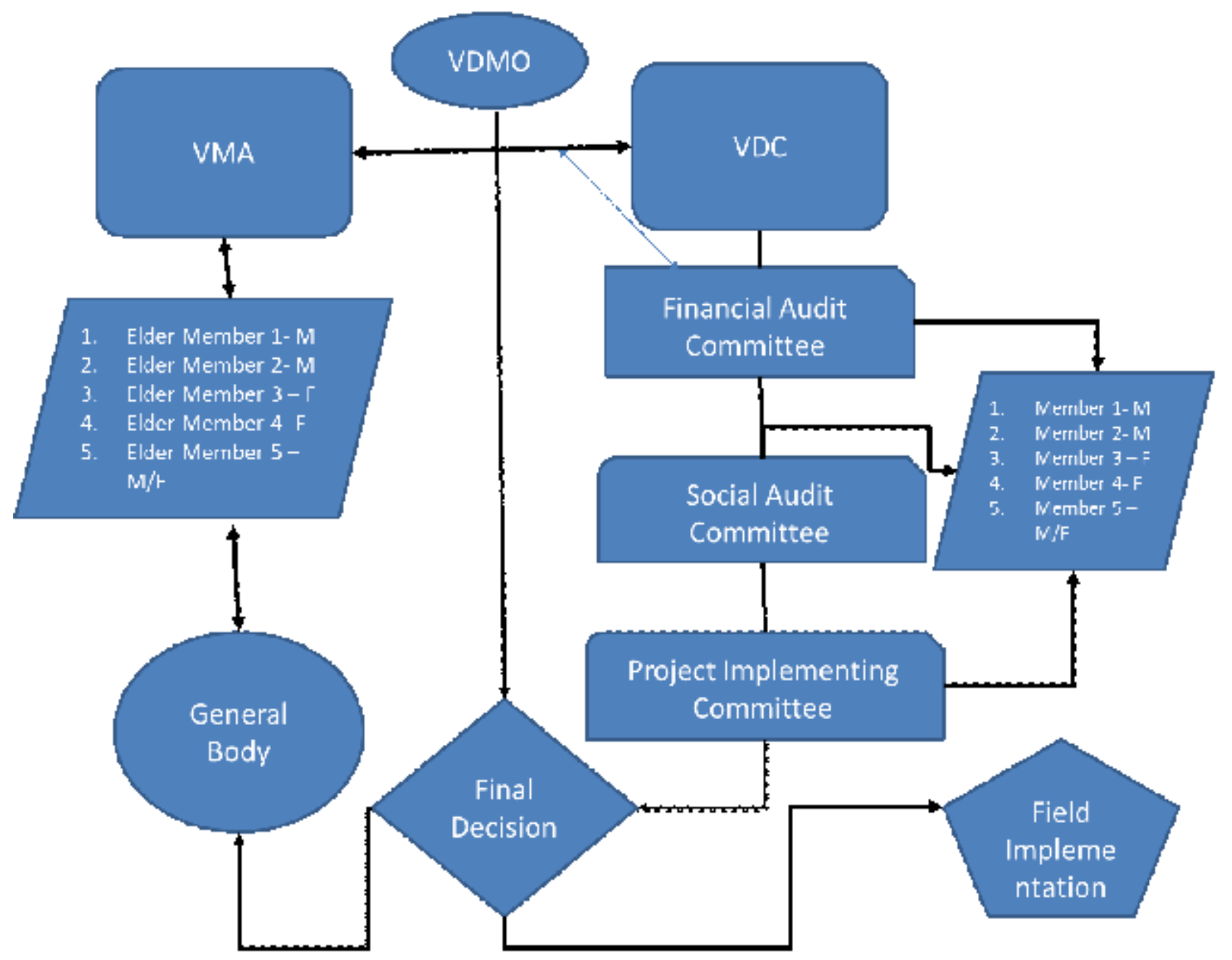

Figure 4. Proposed Three Tier System of Village Development and Management Organization and interactions between its Office bearers.[GB: General Body, VDMO: Village Development and Management Organization, VMA: Village Management Authority, VDC: Village Development Council, FAC: Financial Audit Committee, SAC: Social Audit Committee PIC: Project Implementation Committee].

of Gram Swaraj Act of Madhya Pradesh. Under ATMA alomost all stake holders comprising officials from all state departments and villagers are expected to work in unison in favour of quick pre-mediated actions. However, the role of ATMA was limited to training the farmers and taking them to field visits for crating awareness for growth and development. The newly proposed three tier VDMO and open chain network model allows the existing institutional framework to embrace both decentralized and knowledge-based management of village development activities on watershed basis. The watershed development programs under VDMO with new guidelines on decentralization and people's participation have already initiated policy changes to evolve more meaningful and effective grass root level institutions.

\subsection{Three Tiers of Management System under Village Development and Management Organization (VDMO)}

The VDMO is being proposed as a Three Tiers of Management System not as a replacement of Village Panchayat or Watershed Development Committee or Society (WDS) but as separate and independent body responsible for the overall and comprehensive 
development of village community without having any stake in the position of power or monetory gains. It is purely selfless service of the villagers towards posteriority, community living and upholding the values of our ancestors who have passed on the greate legacy to their next generation so that the erth remains a sustainable and beautiful living spce for the genertions that will follow ours or current ones.

\subsubsection{Village Management Authority (VMA): An Empowered Body of Village Gneral Populace or General Body}

A Village Management Authority will consist of at least Five most elderly members, learned, impartial and experienced as a representative of the general population of the village. Half of these members shall belongto the fair gender and the constitution of such a body will have representation from all strata (Social, Financial and Cultural). Depending upon the village populace, the size may vary. Their role will be to seek the public openion on any mater related to the overall development of the village society and all communities as well as to act as the over all supervisors like the family head of any family. They shall enjoy the full rights in relation to the matter of village development and shall form the core of the VDMO. Unflinching faith, wisdom, forsightness and honesty are the main personality trait of such village elders which will make them the guide, philosopher and motivtors. The commitment, dedication and communication skills of such persons should help them play role of facilitator and create niche position for themselves in the local community. However, such leadership is not common and cannot be instituted easily in the management system. But this also does not alleviate the need for such elements in the grass root level institutions. It is necessary that persons with high moral and ethical standards from the core of the VMA. The position will be voluntary and the office is not likely to offer any material benefits. There is no dearth of publicspirited individuals in any region which are voluntarily prepared to contribute in such efforts. Mechanism may be devised to include such persons in VMA. To further strengthen such organizations, rules and procedures can be incorporated to make it transparent in its working.

http://www.informaticsjournals.com/index.php/sdmimd | Vol 12| Issue 1| March 2021

\subsubsection{Village Development Council (VDC) : Targetting the Grass Root Level}

The Village Mnagement Authority (VDA) will be supported as for as the implementation of the projects and schees are concerned by a body names as Village Development Council (VDC) which in turn comprises three independent commitees having at least five members representing all sections of the village including both genders in each namely; FAC: Financial Audit Committee, SAC: Social Audit Committee, PIC: Project Implementation Committee.

\subsubsection{Financial Audit Committee (FAC)}

A Financial Audit Committee (FAC) is being proposed for VDMO which will work under VDC. It will consist of at least Five most learned members, having ample knowledge of the financial matters in views fo the general body and experienced as a representative of the general population of the village. Half of these members shall belong to the fair gender and the constitution of such a body will have representation from all strata (Social, Financial and Cultural). Depending upon the village populace, the size may vary. Their role will be to keep the records of all expenditures in any project implementation and handle the flow of funds. They shall be answerable to the VMA and the head of VDMO as well as the GB.

\subsubsection{Social Audit Committee (SAC)}

A Social Audit Committee (SAC) is being proposed for VDMO which will work under VDC. It will consist of at least Five most able bodied and strong members, who may be well versed with the social matters related to the village, impartial and experienced as a representative of the general population of the village or GB. Half of these members shall belongto the fair gender and the constitution of such a body will have representation from all strata (Social, Financial and Cultural). Depending upon the village population, the size may vary. Their role will be to seek the public openion on any mater related to the overall development of the village society and all communities as well as to act as the over all supervisors like the family head of any family. They shall also be responsible for any social matters related to any project being implemented in the 
village for its over all development. They shall see that no unjustice is meted out to any group in the village society.

\subsubsection{Project Implementation Committee (PIC)}

A Project Implementation Committee (PIC) is being proposed for VDMO which will work under VDC. It will consist of the most enthusiastic young people who wish to take the village at the next level. This is going to be the most vibrant and active committee havin atleast Five most enthusiastic members, less learned but active and having fighting spirits for realization of the project implementation goals. Half of these members shall belongto the fair gender and the constitution of such a body will have representation from all strata (Social, Financial and Cultural). Depending upon the village populace, the size may vary. Their role will be to see the proper implementation of all projects from any funding agency. It is desired that the project implementing committee should be certifying all works for their quality and adequacy.

\subsubsection{Role of First Tier: The Village Management Authority (VMA)}

As proposed earlier it will consist of a leader of the team perhaps the senior most member. The Village Management Authority (VMA) has been envisaged as the First Tier or a core group of learned elder personnel and a peripheral one (Figure 4). They will be renowned, persons possessing ample wisdom and experience having all senses working, a vision for the future and a zeal to take their people in the next millenia. They all may not be technically competent persons capable of manning the office of high authority but definitely thay shall be able to foresee the implications of any actions and their remifications. Small group of such persons will together provide the leadership and overlook the managerial and coordinating functions of the VMA. The core group personnel, preferably from the local area, will be the persons of repute with impeccable record of honesty and devotion for rural development. The successful programs implemented in different parts of the country have genesis in the honest, sincere and benevolent local leadership which generated self-help to implement the desired program by the community itself. Providing leadership and opportunity to unorganized but willing population to fulfill their dreams was key to the successful implementation of the programs. This important aspect cannot be over looked while making either village or watershed development plans people's own program. These qualities should form the basic requirement of the personnel holding positions in a VMA.

\subsubsection{Role of Second Tier: The Village Development Council (VDC)}

The Second Tier or other group of persons will consist of technical officers derived from different functional areas. Persons from all walks of life like industry, banking, administration, police, law and religions may be extended incentives to become members of VDC and push their programs. Each one will be the program leader for the program proposed and planned by him/ her or their departments. Any stake holder will be free to operationalize the program along with the mechanism for technology development, dissemination and value addition. As a measure to strengthen and develop the rural economy, government may encourage all type of personnel to take part in the activities of VDC. The new VDC is an extension and much more refined version of the older village level development and management institutions that will have the open platform on the principles of free and frank openion building in the favour of any development or community action with proper representation of of all sections, sanction from all the learned elders with gender equity, progressive and modern thinking open ended organization with widely opened arms to embrace the new technology vis-a vis maintining the uniqueness and sanctity of the old village order. Thus, VDC will be the mix of roles of coordinator, facilitator, enabler and regulator. The modus-operandi of its working is elaborated as under:

- Member of VDC will work out system description, problem diagnosis, search for appropriate technology, monitoring and evaluation.

- Direct participation and observations of the expert group in VDC will quickly reveal the major bottlenecks, opportunities and the relevant stake holders having capacity and the willingness to intervene.

- The whole arrangements will ensure an ambience of innovation and demand driven assistance rather 
than pushing pre-determined technology packages and the programmes.

- To impart local characteristic to VDC, it will have the power to make rules, bye-laws for its conduct and amend, add and delete them time to time.

- VDC will also be empowered to create administrative, technical and other posts and make appointments there to.

- The programs in the villages will be implemented through individual household or Users Groups or Self-Help Groups.

\subsubsection{Role of the Third Tier: The Village Development and Management Organization (VDMO)}

There has to be a person at the apex of of all committees and societies as the real commander of all workers. The head of the VDMO may be selected by the general majority. It is proposed that there be no election but the person who shll take the responsibility of VDMO shall have all virtues and be impartial and free from prejudice under whom all people should like to work and hve full faith in him.

\subsubsection{The Main Characteristics of Village Development Society (VDMO)}

- It is restructured or a reorganized Autonomous/ Accountable Body.

- VDMO will be the society of all stake holders having interests in agriculture and rural development.

- It will include government officials, technical experts, industry representatives and NGOs.

- The local population, directly and through selected representatives will be the key constituent of this organization.

- All the stake holders will also be the constituents of Gram Sabha.

- The Sarpanch may act as president of the Gram Sabha with an understanding that decision making process will be facilitated by Gram Sabha and executive functions will be performed by VDMO.

- VDMO will be a focal point institution to coordinate efforts of all the agencies interested in rural development.

- This approach will facilitate collaborations with business groups, key NGOs and other agricultural experts around commonly agreed framework, action plan and outcome.

- Government programs can also be implemented through this body.

- Any NGOs and private sector can initiate interventions on behalf of rural population.

\subsection{Major Operational Area, Role and Functions of VDC : Livelihood Enhancement, Capacity Building and Empowerment}

The VDC will have to see that there are ample opportunities to all the villagers irrespective of their ethanicity, cast, creed or religion. Through ts three committees the Council shall ensure ovar all development. Also, the council shall explore the new possibilities of funding and employment generation opportunities in the village.

\subsubsection{Training and Employment Opportunities for All}

It is necessary that self employment opportunities at the village level must be explored. On the lines of the Industrial Watershed Concept, the resources must be explored for utilization by the village community as well as in case of surplus the samhe need to be shared outside the village. The VDC will ensure capacity building of the local community in agricultural development, animal husbandry, bee keeping and other agro-ventures by facilitating organization of farmers into associations and cooperatives, companies in marketing, agroprocessing and other agricultural related activities. It will ensure that the benefits of the government schemes are allowed to be availed un-hindered by the targeted community and the community is protected from vested interests. However, in no case there shall be partiality or isolation of certain fraction or marginalization of some ethnic group in the matter of opportunity. It is seen that the resource poor and illiterate farmers stand little chance to organize themselves on these lines in absence of such efforts. VDC will device methods to stand surety and negotiate on behalf of these farmers. VDC will also help canalizing financial support through credit institutions, private investments and the training for skill up gradation (Figure 5). 


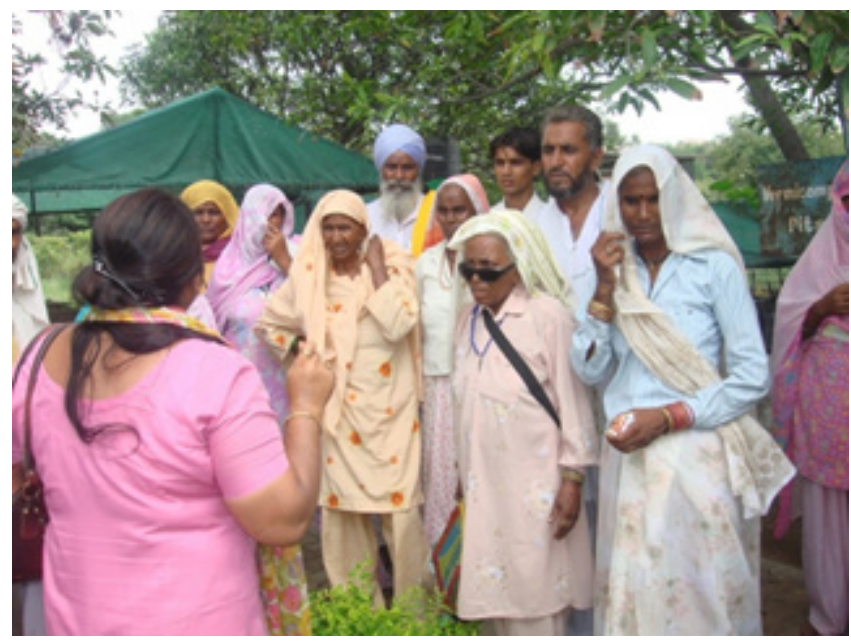

Figure 5. Capacity building for ensuring people's participation.

\subsubsection{Empowerment of Executive and General Masses}

Markets govern the entire cycle of production and development. If there is a demand for some produce either raw or in value added form there will be efforts for its production. The over all development of enterprizes and employement generation activities will depend on the avaialability of information and spread of knowledge regarding what has to be produced processed or marketed. With societal growth and modernization of communication facilities like TV, telephone, internet, and social media plateforms, there is a major shift from production driven agriculture to market driven agro-economic activities. This has become possible with much rapid information flow from the world to the villages which are major production bases of the country. The local community is activated in the regard of production based on the information pertaining to marketability of the products through various channels. One role of the VDMO will also be to arrange the plateforms for making the general maasses aware and educated about the products to be prepared or cultivated. Capacity building for ensuring people's participation is a prerquisite for success of project implementing in any village or rural community. In (figure 5), the women of one of the most backward district namely Mewat (Haryana) and the most backward and downtrodden people of $\mathrm{Meo}$ community were exposed to modern technologies at the WTC by us.
Apart from this the VDMO shall also provide the information on sources, quality, potential of different techniques and the technology used for production and processing as well as marketing of agricultural produce. Perhaps the VDMO can initialize creation f the Frmer's Producers Organization (FPO's) by making clusters of like minded farmers and also the enterprenurial activities may start with the help and cooperation of the community. Further, VDMO, concerned with sustainability issues, need to maintain a wide variety of spatial (geographical) information about conditions and impacts on natural resources, production systems and the socio-economic profile of the region in question. Meaning thereby that whatever economic activities are planned or executed the VDMO shall always look for protection and prevention of the natural resources from being over exploited or polluted hence, maintaining the sustanablity of the essential resources for posteriority.

\subsubsection{Employement, Livelihood and Empowerment Enhancement}

In past, it was required that the VDMOs should conceive both production and economic return system for promoting rainfed farming and watershed activities at the least cost. The shift in the national priorities in late twenties of the millenim with launching of Pradhan Mantri Krishi Sinchayee Yojana (PMKSY) warrants water fr every field. Hence, by adopting many technologies in conjunction with all other water management techniques on watershed basis the village communities have to maximize their production and economic goals. Hence, the role of VDMO has increased from merely, managing the resources to the overall development of the village communities which also include all such activities and plans which generate much needed employement and thus the empowerment of the communities. However, these activities should not become project based onetime activity but convert rainfed farming into irrigated one if possible, being highly profitable, productive and livelihood generating enterprises. VDMO, by virtue of conglomerate of resource persons, will also be the rural knowledge society steering knowledge based farming and other agri-business activities. 


\subsection{The Closed Vertical Chain Business Model based on Agro-indutrial Watershed Concept}

All these years the farming was such an enterprise which was confined to production in bulk. The returns envisaged from the agro-ventures were either no-profit no loss due to faulty method of working out of the cost of cultivation or due to wrong policies of the government. The value addition, marketing and profit realization was being undertaken by the urban communities. Hence, the profit realization was high with lowering the risk components. This has resulted into the present day scenario of the Indian communities especially the rural one. In the changing world and economic order the deep and thorough understanding of social and economic conditions and mutual trust developed by VDMO will help in organizing and integrating rural masses with main stream economic activities with an eye on the profit realization. Although, the initial seed money required will be a great troublemaker yet with the changing economic order, government schemes and policies this will ease out soon. Only precondition will be sound business plans and strategies based on all conceivable value addition and distribution practices which will be pre-requisite for this closed chain business model to be viable and sustainable. The technical support for limited or specific activity may also be obtained through out-sourcing to experienced resource persons/organizations identified by VDMO. It is believed that VDMO can successfully endeavor to create an environment to build partnerships not only locally with other organizations active in rural services and development but also globally with marketing giants and malls. Further, depending on the product quality and requirement, the VDMO can spire to get into export of finished products of various kinds to other regions or countries as the case may be. The business models also provide technical support and advice to produce quality farm output and supply of good quality farm input. Such partnerships, with defined participating local and business groups and value adding business activities, are fully amenable to closed vertical business supply chain network. The demand aggregation and increased market penetration will provide the incentive for rural infrastructure development like food processing, storage and transport etc (Venkatarangaiah and Pattabhiram, 1969). The initial higher cost of infra-structure development and marketing channels will be absorbed through this business model which will help lowering transaction costs and achieving higher business volumes.

From the very basic assumption of watershed management we know that it aspires to keep the costs to bare minimum as compared to the major dam and canalbased irrigation projects. It was an erroneous preposition right from the bigenning because one can not move mountains with needles or shovels in my view. In the bigenning when the concept was originating perhaps the target was large areas with very small purse. Hence, in the bigenning the cost of developments were only a very small fraction of wht was required. Hence, the large numbers of so called successful watershed management programs or in rainwater harvesting those were implemented by the social leaders or local organizations, have demonstrated their efficiacy to very limited level; leaving much larger scope for exploration.

On the contrary where there were no funds available for undertaking any community oriented project or works the people's participation has proved its merit beyond doubt. The jobs could be completed with crowd funding or donations. In some cases the local community of the watershed raised the whole amount through their personal contributions and donations in cash and kind including the cost of labour through free Shramdaan or labour. While the cost component on government funded projects or scheme have to follow a strict guidelines and the inbuilt provisions encompass various overheads, in the absence of cumbersome procedures and rent seeking elements, the local community could accomplish the task at much lower cost with superior quality of construction. The amicability of business model to this sphere of activity, is too good so much so that immediate solution provided by such measures made such investments quite attractive and the local society reaped the benefits immediately. Such institutions need to be viewed as a platform for providing services in water harvesting, community irrigation, watershed management, resources generation, other livelihood 
options and common property resources management like pasture lands and better exploitation of minor and major forests produce. However, such experiments have not been able to spread far and wide as well as not have shown much interest in generating revenue and maintaining and improving the capacity of such endeavors, possibly due to absence of institutional and legal backing. Although, participatory regulatory institutional mechanism has the provision for collection of fees for extending advisory or managerial services but this option has not been explored so far and need to be developed, amalgamated in the participatory rural management concept and strengthened further for upscaling.

Therefore, a new grass root level institution VDMO has been envisaged, enabling non-participating or, at best, passively participating rural population to be party to socio-cultural and economic growth and development which is the daunting requirement for a sustained and continuous overall growth in rural Indian agricultural and natural resources management sector. Such an organization has the capability to eradicate corruption (economic, social and cultural) from the society and bring the much needed tranquility and equity in the maters of natural resources management, use and upkeep vis-à-vis ensuring over all development and growth of one and all. The key words in this experiment would be honesty, hard work, tranquility, zeal to progress and selflessness.

\section{Conclusion}

In this study a new model for the overall development and management of resources of the rural agrarian economy of India has been envisaged which will work on the principles of honesty, hard work, tranquility, zeal to progress and selflessness to realize the goals of over all socio-cultural and economic progress of all beneficiaries without sacrificying their personal identities or without having to leave or migrate with limited resources. Such grass root level institution, called Village Development and Management Organization (VDMO), will be working in close association with rural masses and will have responsibility to protect their interests. It will create strong and transparent processes in local resources management, conceiving and field implementation of developmental projects, employment generation ventures, capacity building and bringing in enormous happiness without and socio-cultural or economic biases. The development of grass root level institutions is central to sustainable agricultural development, inclusive of healthy natural resource base and redistribution of income in favour of resources poor farmers to enable the local communities to be part of the whole in the matters of planning, execution and revie the overall progress with dignity and self respect. The reform process, initiated in agricultural sector as a sequel to general decentralization and liberalization in the economy, need to be strengthened by conclusively targeting the basic requirements of this sector especially downtrodden and landless masses. The social issues in natural resource management are the real challenges which VDMO will be facing and justifying its own existence. The cooperation and the assistance rendered in rest of the activities and existing social and legal laws will provide enough authority to VDMOS to this end. Based on the success of the model, one day the present developmental decentralization models of out country may be modified to incorporate the best provisions.

However, looking at the huge diversity in the country (topographic, physiographic, climatic and ethnic) no single model could be applied across the country with great success. But, as the country has acquired the status of a single union after adopting the constituion in 1947 and the local decentralization in 1972, it is likely that under one nation theory the most successful model of local community development, resources conservation and management on watershed basis may be wholeheartedly adopted by all. Institutional innovation at the community level has to be a continuous process and must be experimented with in order to evolve functional VDMOs. A general liberal policy framework in public domain, like easy access to information, inputs and capital, creation of production bases, developing alternate marketing channels in procurement, processing, storage and trans-border movements will also be important requirements for this model to be successful. Fully defined and clear property rights and entitlement to benefit from public land will help creating necessary 
capital resources in rural sector. It is our strongest belief that the new VDMO model of people self-government will not only be able to transform the natural resources, generate livelihood, empower people but also generate the much needed livelihood option and help in doubling or quadrupling the much need income and purchasing capacity of rural masses vis-a-vis the long term sustainability of the natural resources for mankind. If the basic principles of unbiaseness, honesty and selflessness are observed then there is no failing of this model which will take India in next millenia and make it a forerunner, well developed and strong nation; socially, culturally, economically with long term sustainability of its natural resources base of all kinds.

\section{References}

Anirban, K. (1989). Panchayti raj, views of founding fathers and recommendation of different committees, New Delhi, Lancer Books, 109.

Anonymous (1957). Report of the team for the study of community projects and national extension service, (Chairperson: Balvantray Mehta), Committee on Plan Projects, National Development Council, Vol. I, New Delhi.

Anonymous (2020). Take five: Elected women representatives are key agents for transformational economic, environmental and social change in India. UN Women.

Aziz, A., Sivanna, N., Babu, M. D., Madhushree, S. \& Nelson, C. C. (2002). Decentralized governance and planning: A comparative study in three South Indian States, Macmillan, New Delhi.

Babu, M. D. (2005). Decentralized planning in Karnataka: An impact study. In A C K Nambiar and C R Pathak (Eds), Decentralized Planning and E-Governance in India: Problems and Prospects, Department of Economics, University of Calicut, Kerala.

Babu, M. D. (2009). Financial Empowerment of Local Governments in the Indian Context: A Myth or Fact?- A Macro Enquiry. Asian Studies Review, No.7.

Bahl, R.W. (2002). Implementation rules for fiscal decentralization. In M G Rao (Ed), Development, Poverty and Fiscal Policy: Decentralization of Institutions, Oxford University Press, New Delhi.

Balakrishnan, R. (2007). Participatory pathways: People's participation in development initiatives. Pearson Education India, ISBN 978-81-317-0034-1.
Beseley, T., Pande, R., and Rao, V. (2008). The political economy of gram panchayats in South India. In G K Kadekodi, R Kanbur and V Rao (eds) Development in Karnataka: Challenges of Governance, Equity and Empowerment. Academic Foundation: New Delhi.

Bhargava, B. S., \& Raphel, C. J. (1994). Working of grama sabhas in Karnataka: A study at micro level. Journal of Rural Development. 13(2), 145-158.

Bird, R. (2000). Intergovernmental fiscal relations: Universal principles, local applications, Andrew Young School of policy studies, Georgia State University, Georgia.

Bollongino, R., Nehlich, O., Richards, M. P., Orschiedt, J., Thomas, M. G., Sell, C., Fajkošová, Z., Powell, A., \& Burge, J. (2013). 2000 Years of Parallel Societies in Stone Age Central Europe. Science. 342 (6157), 479481. https://doi.org/10.1126/science.1245049

Chattopadhyay, R., \& Duflo, E. (2004). Women References: As Policy Makers: Evidence from a randomised policy experiment in India. Econometrica. 72(5), 1409-1443. https://doi.org/10.1111/j.1468-0262.2004.00539.x

Fahim, M. (2009). Local government in India still carries characteristics of its colonial heritage. City Mayors Foundation.

George, M. (2000). Status of panchayati raj in the States and Union Territories of India.Concept for Institute of Social Sciences, Delhi.

IMD (2020). Climate of India. (www.imd.gov.in).

GOI (1993). The constitution (Seventy third amendment) Act, 1992, The Gazette of India, Ministry of Law, Justice and Company Affairs, New Delhi, 1993.

Hardgrave, R. L., \& Kochanek, S. A. (2008). India: government and politics in a developing nation (seventh ed.). Boston, Massachusetts: Thomson/Wadsworth.

Inbanathan, A. (2003). Affirmative action and dalits: Political representation in panchayats. ISEC Working Paper No. 138.

Inbanathan, A., \& Sivanna, N. (2010). Scheduled castes, legitimacy and local governance: Continuing social exclusion in panchayats. ISEC Working Paper No. 257.

Mathew, G. (1994). Panchayat Raj: From legislation to movement. Concept. New Delhi.

Mullick, R., \& Raaj, N. (2007). Panchayats turn into kangaroo courts. The Times of India.

NCERT (2019). www.ncert.nic.in.

Nehru, J. L. (1964). The Discovery of India, Signet Press, Calcutta, p.288.

Pellissery, S. (2007). Do multi-level governance meet local aspirations? Asia Pacific Journal of Public 
Administration. 28(1), 28-40. https://doi.org/10.1080/2 3276665.2006.10779313

Rajaraman, I., \& Garima, V. (2000). Impact of grants on tax effort of local government. Economic and Political Weekly, XXXV: 30 (12 August): 2943-2948.

Rajasekhar, \& Manjula. (2010). Revenues of gram panchayats in Karnataka. Bangalore: Institute for Social and Economic Change (mimeo).

Ram D. S. (2008). Role of panchayati raj institutions in 60 years of independent India: Vision of the Future, Academy of Grassroots Studies and Research of India and Kanishka Publishers, Distributors,New Delhi, 414.

Rao, M. G., Nath, H. K. A., Vani B. P. (2004). Rural fiscal decentralization in Karnataka state. Fiscal Decentralization to Rural Local Governments in India, World Bank.

Sharma, M. L. (1987). Gandhi and democratic decentralization in India. New Delhi: Deep and Deep Publications. OCLC 17678104.

Singh, V. (2003). Panchayate Raj and Gandhi. Panchayati Raj and Village Development: Volume 3, Chapter 5:
Perspectives on Panchayati Raj Administration. Studies in public administration. New Delhi: Sarup \& Sons.

Sisodia, R. S. (1971). Gandhiji's vision of panchayati raj. Panchayat Aur Insan. 3(2), 9-10.

Thomas, I. T. M. and Richard W. F. (2000). Local Democracy and Development, Left World Books, 12, Rajendra Prasad Road, New Delhi 110 001, India.

Udgaonkar, P. B. (1986). Political Institutions \& Administration, Motilal Banarasidass Publishers.

Venkatarangaiah, M., \& Pattabhiram, M. (1969). Local government in India: Select Readings, Allied Publishers, New Delhi.

Vijayalakshmi, V. (2007). Differences and Identities: Women and political participation. In T M Joseph (ed.) Local Governance in India: Ideas, Challenges and Strategies, Concept Publishing Company.

World Bank. (2000). Overview of rural decentralization in India Volume III World Bank. 